University of Nebraska - Lincoln

DigitalCommons@University of Nebraska - Lincoln

Educational Psychology Papers and

Publications

Educational Psychology, Department of

2011

\title{
The Role of Classroom Quality in Ameliorating the Academic and Social Risks Associated with Difficult Temperament
}

Timothy W. Curby

George Mason University, tcurby@gmu.edu

Kathleen Moritz Rudasill

University of Nebraska-Lincoln, kmrudasill@vcu.edu

Taylor Edwards

George Mason University

Koraly Pérez-Edgar

George Mason University, kperezed@gmu.edu

Follow this and additional works at: https://digitalcommons.unl.edu/edpsychpapers

Part of the Educational Psychology Commons

Curby, Timothy W.; Rudasill, Kathleen Moritz; Edwards, Taylor; and Pérez-Edgar, Koraly, "The Role of Classroom Quality in Ameliorating the Academic and Social Risks Associated with Difficult Temperament" (2011). Educational Psychology Papers and Publications. 122.

https://digitalcommons.unl.edu/edpsychpapers/122

This Article is brought to you for free and open access by the Educational Psychology, Department of at DigitalCommons@University of Nebraska - Lincoln. It has been accepted for inclusion in Educational Psychology Papers and Publications by an authorized administrator of DigitalCommons@University of Nebraska - Lincoln. 
Published in School Psychology Quarterly 26:2 (2011), pp. 175-188; doi: 10.1037/a0023042

Copyright (C) 2011 American Psychological Association; published by Elsevier. Used by permission.

This study was conducted by the NICHD Early Child Care Research Network supported by NICHD through a

cooperative agreement that calls for scientific collaboration between the grantees and the NICHD staff.

\title{
The Role of Classroom Quality in Ameliorating the Academic and Social Risks Associated with Difficult Temperament
}

\author{
Timothy W. Curby, ${ }^{1}$ Kathleen Moritz Rudasill, ${ }^{2}$ Taylor Edwards, ${ }^{1}$ and Koraly Pérez-Edgar ${ }^{1}$ \\ 1. Department of Psychology, George Mason University \\ 2. Department of Educational and Counseling Psychology, University of Louisville \\ Corresponding author - Timothy W. Curby, Department of Psychology, MS - 3F5, \\ George Mason University, 4400 University Dr., Fairfax, VA 22031; email tcurby@gmu.edu
}

\begin{abstract}
The present study examines the moderating role first grade classroom quality may have on the relations between children's difficult temperament (assessed in infancy) and their academic and social outcomes in early elementary school (first grade). Using data from the National Institute of Child Health and Human Development's Study of Early Child Care and Youth Development, 1032 children were rated by their mothers at 6 months of age on difficult temperament. The quality of first grade classroom environments were then observed and rated along three domains: emotional support, classroom organization, and instructional support. Regression analyses examined the statistical interactions between difficult temperament and classroom quality domains on children's academic and social outcomes. Results indicate high-quality classroom environments may ameliorate the academic and social risks associated with having a difficult temperament.
\end{abstract}

Keywords: classroom quality, difficult temperament, first grade

Children's early academic and social success in elementary school is critical for their long-term success (e.g., Adams, 1990; Hart \& Risley, 1995). For example, academic success during the first 3 years of formal school (i.e., kindergarten through second grade) establishes a positive trajectory for academic achievement (Alexander, Entwisle, \& Dauber, 1993). However, not all children enter school with an equal opportunity to succeed. Some characteristics of children, such as having a more difficult temperament, promote or hinder children's success in school. Difficult temperament may sensitize children to particular aspects of the classroom environment (e.g., a teacher's sensitivity to individual differences) and place children at risk for a lower academic trajectory. Indeed, research on children's difficult temperament points to negative associations with academic and social outcomes (e.g., Molfese et al., 2010; Stright, Gal- lagher, \& Kelly, 2008). At the same time, there is growing support for the role of classroom quality in children's academic and social success (Mashburn et al., 2008; Rimm-Kaufman, Curby, Grimm, Nathanson, \& Brock, 2009). Thus, the present study examines how temperament and classroom quality work in combination by evaluating the moderating role first grade classroom quality has on the relations between children's difficult temperament (assessed in infancy) and their academic and social outcomes (reported in first grade).

\section{Early Academic and Social Success}

Children's early academic and social success in school has implications for their later success. It is hard to dispute the importance of early academic success for long-term academic achievement (Duncan et al., 2007). Work by Alexander 
and colleagues (e.g., Alexander et al., 1993) shows that differences in early academic achievement are related to continued and growing gaps across development. Furthermore, these studies point to the role of moderators such as socioeconomic status in predicting academic achievement trajectories, as well as within-child characteristics that promote or hinder success in the school environment (Alexander et al., 1993; Hart, Atkins, \& Fegley, 2003; Keogh, 2003).

With regard to social success, there is abundant research indicating the quality of children's early relationships with their teachers is predictive of a host of concurrent and future outcomes such as academic achievement (Birch \& Ladd, 1997; Liew, Chen, \& Hughes, 2010) and social and behavior difficulties (Baker, 2006; Birch \& Ladd, 1997; Ewing \& Taylor, 2009). In addition, there is growing evidence that these relationships are predicated, in part, on children's temperament characteristics. For example, the work of Rudasill and colleagues (Rudasill \& Rimm-Kaufman, 2009; Rudasill, Rimm-Kaufman, Justice, \& Pence, 2006) converges on the notion that children with characteristics of a difficult temperament (such as higher shyness, lower regulation, or higher activity) are likely to have relationships with teachers in elementary grades marked by higher levels of conflict and lower levels of closeness. Taken together, research suggests children's temperament is associated with early academic achievement and teacher-child relationships, and these early academic and social outcomes establish trajectories for long-term outcomes in school.

\section{Difficult Temperament}

Temperament is an individual's style of responding to people, events, and other environmental stimuli (Caspi, Bem, \& Elder, 2006; Garcia Coll, Kagan, \& Reznick, 1984; Rothbart, Ahadi, \& Evans, 2000). It is biologically based, relatively stable through childhood, and multidimensional. Although there are some variations across specific studies, "difficult" or "negative" temperament is usually characterized by the presence of negative emotionality coupled with reports that the child's behavior is hard to manage (Prior, 1992). As such, the specific components of "difficult" temperament can vary with measurement scheme. For ex- ample, high levels of overactivity and low-levels of soothability can contribute to a difficult temperament. Extremely shy children who are unable to adapt to novel or unfamiliar social settings and react with high levels of negative affect are often labeled difficult. To capture a broad profile of difficult temperament, the current study included measures of wariness in approaching novel stimuli, high activity level, intense responses, generally negative mood, and difficulty in adapting to new situations or people (Carey, 2005; Thomas \& Chess, 1977).

Children with more difficult temperaments may face greater challenges when adjusting to formal schooling than those with easier temperaments and, therefore, a lower probability of succeeding in school. For example, findings from research by Martin and colleagues (Martin \& Holbrook, 1985; Martin, Drew, Gaddis, \& Moseley, 1988) indicate children's higher activity level (one aspect of a more difficult temperament) is related to poorer academic achievement in early elementary grades. In a recent study by Stright et al. (2008), using data from the National Institute of Child Health and Human Development (NICHD) Study of Early Childcare and Youth Development (SECCYD), children's higher ratings for difficult temperament in infancy were associated with poorer academic adjustment in first grade.

However, difficult temperament alone does not produce these worse outcomes in children. Rather, children's outcomes arise from the fit between temperament and the environment. In certain environments, children with difficult temperaments may be able to flourish just as much as, if not more than, their peers with easier temperaments (Belsky $\&$ Pluess, 2009). In other words, there is a potential match (or mismatch) between the characteristics of the person and the demand and support characteristics of the school (Eccles et al., 1993) or home (Lerner, 1983) environments. For the purposes of the present study, we explore the degree to which the quality of the classroom environment may moderate the association between difficult temperament and children's outcomes.

A review of the literature indicates that abundant research attention has been given to the impact of home environment, particularly parenting behavior, on subsequent socioemotional and cognitive development in light of temperamental dif- 
ferences (e.g., Ghera, Hane, Malesa, \& Fox, 2006; Hane, Cheah, Rubin, \& Fox, 2008). Researchers have found parenting behaviors moderated the association between difficult temperament in infancy and children's academic (Stright et al., 2008) and behavioral (Bradley \& Corwyn, 2009) outcomes in first grade. Bradley and Corwyn (2009) found children with difficult temperaments in infancy were more likely to have higher teacher-reported externalizing behavior in first grade if they experienced harsh parenting. Conversely, children were more likely to have lower teacher-reported externalizing behavior if they experienced sensitive parenting. Similarly, Stright et al. (2008) found children with more difficult temperaments had higher ratings than children with less difficult temperament for academic competence and social skills in first grade when parenting was more supportive and had lower ratings than children with less difficult temperaments when parenting was less supportive.

In contrast, there has been relatively little focus, using a comparable point of view, on the role of the school environment on associations between temperament and academic and social development (see Rimm-Kaufman et al., 2002 and Rudasill, Gallagher, \& White, 2010 for exceptions). Starting in first grade (and earlier for many children), children spend the entire day at school. Thus, the current paper expands our study of development into an important and large realm of influence. Clearly, future work will need to focus on the reciprocal and ongoing relations between the school and home and the subsequent impact on development. This is an important future avenue of study dependent on having a strong and nuanced understanding of processes within each environment. To the extent that researchers, parents, and school personnel are interested in outcomes that are directly related to the context of the classroom, then it makes sense to see how the classroom works to shape these outcomes. As such, we explored the classroom context as a potential moderator of the relations between temperament and outcomes (Rimm-Kaufman et al., 2002; Rudasill, Gallagher, et al., 2010).

\section{Classroom Quality}

Classroom quality plays a critical role in shaping children's outcomes. A central marker of class- room quality is the global quality of teachers' interactions with children. This view of quality is consistent with the bioecological model of development (Bronfenbrenner \& Morris, 2006), which states proximal processes - the increasingly complex reciprocal interactions between a person and his or her environment-drive development. From this perspective, to understand children's experiences in classrooms, it is necessary to observe the proximal processes that take place in these classrooms - in this case, the quality of teachers' interactions with children.

On the basis of theoretical (Hamre \& Pianta, 2007) and empirical (Hamre, Pianta, Mashburn, \& Downer, 2007) work, the quality of the interactions children experience in a classroom can be divided into three domains: emotional support, classroom organization, and instructional support. Emotional support refers to the teacher's ability to create a positive classroom climate, meet individual student needs, and provide an atmosphere that promotes student choice and responsibility (Pianta, La Paro, \& Hamre, 2008). Higher levels of emotional support have been linked with greater levels of children's social competence and engagement as well as lower levels of problem behaviors (Mashburn et al., 2008; NICHD ECCRN, 2003). Importantly, emotional support interacts with individual differences to shape children's outcomes. For example, high levels of emotional support have been found to ameliorate some negative elements of risk (e.g., low sustained attention) with children's achievement in first grade (Hamre \& Pianta, 2005).

Classroom organization refers to the teacher's ability to create an atmosphere where behavioral problems do not get in the way of learning, where there is always something for students to work on, and where there are a variety of ways for students to engage in material (Pianta, La Paro, et al., 2008). Higher levels of classroom organization have been linked with higher levels of self-regulation in children (Rimm-Kaufman et al., 2009).

Instructional support refers to a teacher's ability to promote deep thinking about concepts and provide constructive feedback that helps students further engage in the material (Pianta, La Paro, et al., 2008). Higher levels of instructional support have been linked with greater academic learning in children (Curby, LoCasale-Crouch, et al., 2009; Hamre \& Pianta, 2005). Like emotional support, 
there is some evidence that instructional support interacts with individual differences. For example, instructional support may be more beneficial for children whose mothers have lower levels of education (Hamre \& Pianta, 2005).

\section{The Present Study}

The present study examines how maternal report of infant temperament and first grade classroom quality combine to predict children's academic achievement and teacher-child relationship quality in first grade with two research questions. First, do the three domains of classroom quality (emotional support, classroom organization, instructional support) moderate the association between difficult temperament and academic outcomes? Second, do these domains of classroom quality moderate the association between children's difficult temperament and conflict and closeness with a teacher?

\section{Method}

\section{Participants}

Participants were drawn from the NICHD SECCYD. This large, epidemiological study followed children from birth through age 15 . In total 1,364 children were enrolled in the study. Much information about the study, including the selection procedures, is available at https://secc.rti.org/ . By the time children were in first grade, data were available on 1032 of the participants. Of the remaining children, $50 \%$ were female, which was not statistically different than the original sample $\left(x^{2}=.61, d f=1, p=.43\right)$. The majority were white $(83 \%)$, followed by African American (11\%), Hispanic $(5 \%)$, and other $(2 \%$ combined), which was not statistically different than the original sample $\left(\chi^{2}=4.14, d f=3, p=.25\right)$. The sample had an average income-to-needs ratio of 3.68 , which was not statistically different than the sample at 36 months $\left(t_{1206}=.591, p=.55\right)$. Students were in first grade classrooms where $96 \%$ of the teachers were women and $94 \%$ were Caucasian.

\section{Measures}

Temperament. Temperament was measured when children were 6 months old using an ad- aptation of the Infant Temperament Questionnaire (ITQ; Carey \& McDevitt, 1978). Mothers responded using a 6 -point Likert scale $(1=a l$ most never, $2=$ rarely, $3=$ usually does not, $4=u s u$ ally does, 5 = frequently, 6 = almost always) on 55 items. Items on the questionnaire are intended to measure temperament on five dimensions: Approach (11 items, e.g., "My baby is shy [turns away or clings to mother] on meeting another child for the first time"); Activity (13 items, e.g., "My baby moves about much [kicks, grabs, squirms] during diapering and dressing"); Intensity (10 items, e.g., "My baby greets a new toy with a loud voice and much expression of feeling [whether positive or negative]"); Mood (10 items, e.g., "My baby is fussy or cries during the physical examination by the doctor"); and Adaptability (11 items, e.g., "My baby requires introduction of a new food on three or more occasions before he or she will accept [swallow] $\left.i^{\prime \prime}\right)$. After reversing appropriate items, an average difficult temperament aggregate was created across all 55 items. The internal consistency for the difficult temperament aggregate was .81 from this dataset. Higher scores indicate a more difficult temperament.

Classroom quality. Global ratings of classroom quality were measured by the Classroom Observation System at first grade (COS-1). During the winter or early spring, classrooms were observed for an entire day (excluding recess, lunch, and nap) for several 44-min cycles. During each cycle of observation, classrooms were rated on a 7-point Likert scale from $1=$ uncharacteristic to $7=$ extremely characteristic across nine dimensions. On the basis of current conceptualizations of classroom quality (Pianta, La Paro, et al., 2008) and empirical work using this conceptualization (Hamre et al., 2007), three domains of quality were constructed from these nine dimensions: emotional support, classroom organization, and instructional support. Emotional support consisted of four items ( $a$ $=.88$ ): positive emotional climate, negative emotional climate (reversed), teacher sensitivity, and overcontrol (reversed). Classroom organization consisted of two items $(\alpha=.62)$ : behavior management and child responsibility. Instructional support consisted of three items $(\alpha=.65)$ : instructional conversation, quality of feedback, and literacy instruction.

The COS-1 used in the NICHD SECCYD is the 
precursor to the Classroom Assessment Scoring System (CLASS; Pianta, La Paro, et al., 2008), a classroom observation tool with sound evidence of validity and reliability of scores. The CLASS and COS-1 share many of the same items (e.g., positive climate, teacher sensitivity). Other dimensions are similar, but not the same, across measures such as Overcontrol in COS-1, which was eventually reversed and broadened to become Regard for Student Perspectives in the CLASS. Other items (e.g., instructional conversation) were modified and replaced.

Before rating classrooms, all coders underwent extensive reliability training. Training consisted of attending a workshop at which videos of actual classrooms were observed, discussed, and coded. All trainers read a manual with descriptions and examples of classrooms that would be scored at the various levels. In the reliability test, each coder watched five 20-min segments of classroom interactions. Their scores were compared with master ratings. To be deemed reliable, $80 \%$ of a coder's ratings needed to be within 1 scale point of the master ratings. All coders met or exceeded this level of reliability before conducting observations.

Demographic information. Mothers reported on their children's gender at birth and family income when children were 36 months old. Family income was converted into an income-to-needs ratio by dividing the total family income by the poverty level income for that family size based on U.S. Census data. An income-to-needs ratio of 3.0 indicates middle-class economic status (Conger, Conger, \& Elder, 1997). The income-to-needs ratio was chosen at 36 months to get the best estimate of the family's socioeconomic status during early childhood.

Academic outcomes. In the spring of first grade, teachers rated each study child using the Academic Rating Scale (National Center for Education Statistics, no date; see also https://secc.rti. org/ for more information) to measure academic skills. The 25-item scale $(a=.96)$ measures language and literacy (16 items) and math thinking (9 items). All items on the scale are measured on a 5 -point Likert scale ranging from $1=$ not yet demonstrated through $5=$ proficient. These scores were averaged to form Academic Rating Scale Total Skills score representing the child's broad achievement levels.
The Mock Report Card (Pierce, Hamm, \& Vandell, 1999) is a 19-item measure used to measure positive school-related behaviors. In the spring of first grade, teachers assessed each study child across three dimensions. Current School Performance (i.e., grades) rated performance across six school subjects: reading, mathematics, oral language, written language, science, and social studies. Each child was rated using a 5-point Likert scale ranging from $1=$ failing to $5=$ excellent. Work Habits (e.g., "follows classroom procedures") were rated with six items on a 5-point Likert scale ranging from $1=$ very poor to $5=$ very good. Social and Emotional Skills (e.g., "is socially aware of what is happening in a situation") were rated using seven items on a 5 -point Likert scale from $1=$ very poor to 5 very good. For each year, a total score was created by averaging these three dimensions $(\alpha=.96)$, with higher scores indicating positive school-related behaviors.

Social outcomes. Teacher-child relationship quality in first grade was measured using a shortened version of the Student-Teacher Relationship Scale (STRS; Pianta, 2001). Teachers reported on their perceptions of closeness and conflict with the study child using 15 items. Closeness measures positive interactions with the sum of eight items ( $a$ $=.88$ ), such as "When I praise this child, he or she beams with pride." Higher Closeness scores indicate more closeness between the teacher and study child. Conflict measures negative interactions with the sum of 7 items $(\alpha=.85)$ such as "This child and I always seem to be struggling with each other." Higher Conflict scores indicate more conflict between the teacher and study child.

\section{Data Analysis}

Multiple imputation was conducted to account for missing data. Multiple imputation is arguably the best way to deal with missing data in that it leads to less-biased estimates than listwise deletion or single imputation (McKnight, McKnight, Sidani, \& Figueredo, 2007). Five complete datasets were imputed using NORM Version 2.03 software (Schafer, 1997) from the one original dataset that had missing data. Identical multiple regression analyses were then conducted on each dataset. In each case, gender, income-to-needs ratio, difficult temperament, and the three classroom 
quality domains (emotional support, classroom organization, and instructional support) were entered in the first block. Values for income-toneeds, difficult temperament, and classroom quality domains were centered in accord with Aiken and West's (1991) guidelines for regression analyses. Evaluation of the research questions involved examining the interactions between difficult temperament and classroom quality domains. Correlations revealed concerns about multicollinearity; therefore, each interaction was tested separately in the second block. Coefficients and $t$ tests were then aggregated across the five datasets to determine standardized and unstandardized estimates of each predictor as well as corresponding significance levels.

\section{Results}

Table 1 presents descriptive statistics and correlations for all variables used in the analysis based on the original (i.e., nonimputed) dataset. Missing data ranged from $0 \%$ to $6.8 \%$ across variables, supporting our use of multiple imputation. The number of missing cases for each variable is noted in the descriptive statistics. Our choice of control variables (gender, income-to-needs) was supported by correlations among variables whereby male children were more likely to be in classrooms with lower levels of classroom organization $(r=$ $-.11, p<.01)$ and instructional support $(r=-.09$, $p<.01$ ). Males also had worse school-related behaviors and grades as indicated by the Mock Report Card $(r=-.17, p<.01)$, more conflict $(r=.17$, $p<.01)$, and less closeness $(r=-.17, p<.01)$ with teachers. Correlations also indicated that children with higher income-to-needs were more likely to be rated as having a less difficult temperament $(r$ $=-.13, p<.01)$ and be in classrooms with higher levels of emotional support $(r=.16, p<.16)$, classroom organization $(r=.12, p<.01)$, and instructional support $(r=.08, p<.05)$. Children with higher income to needs also had higher academic ratings (Academic Rating Scale $r=.18, p<.01$; Mock Report Card $r=.23, p<.01$ ) and less conflict $(r=-.11, p<.01)$ with teachers. In terms of our predictors of interest, having a more difficult temperament was negatively correlated with academic outcomes (Academic Rating Scale $r=-.09$, $p<.01$; Mock Report Card $r=-.08, p<.01$ ) but not teacher-child relationship quality. Small correlations were evident between the domains of classroom quality and the academic and social outcomes. Academic outcomes were correlated with one another $(r=.67, p<.01)$ and with the social outcomes ( $r$ 's ranged from -.49 to $.39[p<.01])$. Teacher-child conflict and closeness correlated with one another $(r=-.28, p<.01)$.

Table 2 summarizes the results of our regression models. Because each interaction was tested separately, the top half of the table reports the results of the main effects-only models, whereas the bottom half includes the results of the separate interaction models. The main effects models presented on the top half of Table 2 indicate male students were reported to have lower grades than female students by their teachers on the Mock Report Card $(b=-0.24, p<.001)$. Male students were also reported to have less closeness $(b=-1.64, p$ $<.001)$ and more conflict $(b=1.59, p<.001)$ with their teachers. Children with higher income-toneeds ratios were likely to also have higher scores on the Academic Rating Scale $(b=.05, p<.001)$ and the Mock Report Card $(b=.05, p<.001)$, as well as less teacher-child conflict $(b=-0.14, p<$ .01). Children with more difficult temperaments were perceived as having fewer academic skills (Academic Rating Scale $b=-0.18, p<.01$ ) and fewer positive school-related behaviors (Mock Report Card $b=-.13, p<.05)$. In addition, children with more difficult temperaments were less likely to have closeness with teachers $(b=-0.87, p<.05)$. Of the three classroom quality variables (emotional support, classroom organization, instructional support), only classroom organization had a significant main effect. Specifically, classroom organization was positively related to Mock Report Card scores $(b=.08, t=2.74, p<.01)$.

Of primary interest in the present study are the moderating effects of emotional support, classroom organization, and instructional support on associations between children's difficult temperament and their academic and social outcomes. As shown on the bottom section of Table 2, interactions between difficult temperament and the emotional support and instructional support classroom quality domains predicted both academic and social outcomes. No organizational support $\times$ difficult temperament interactions were significant. 


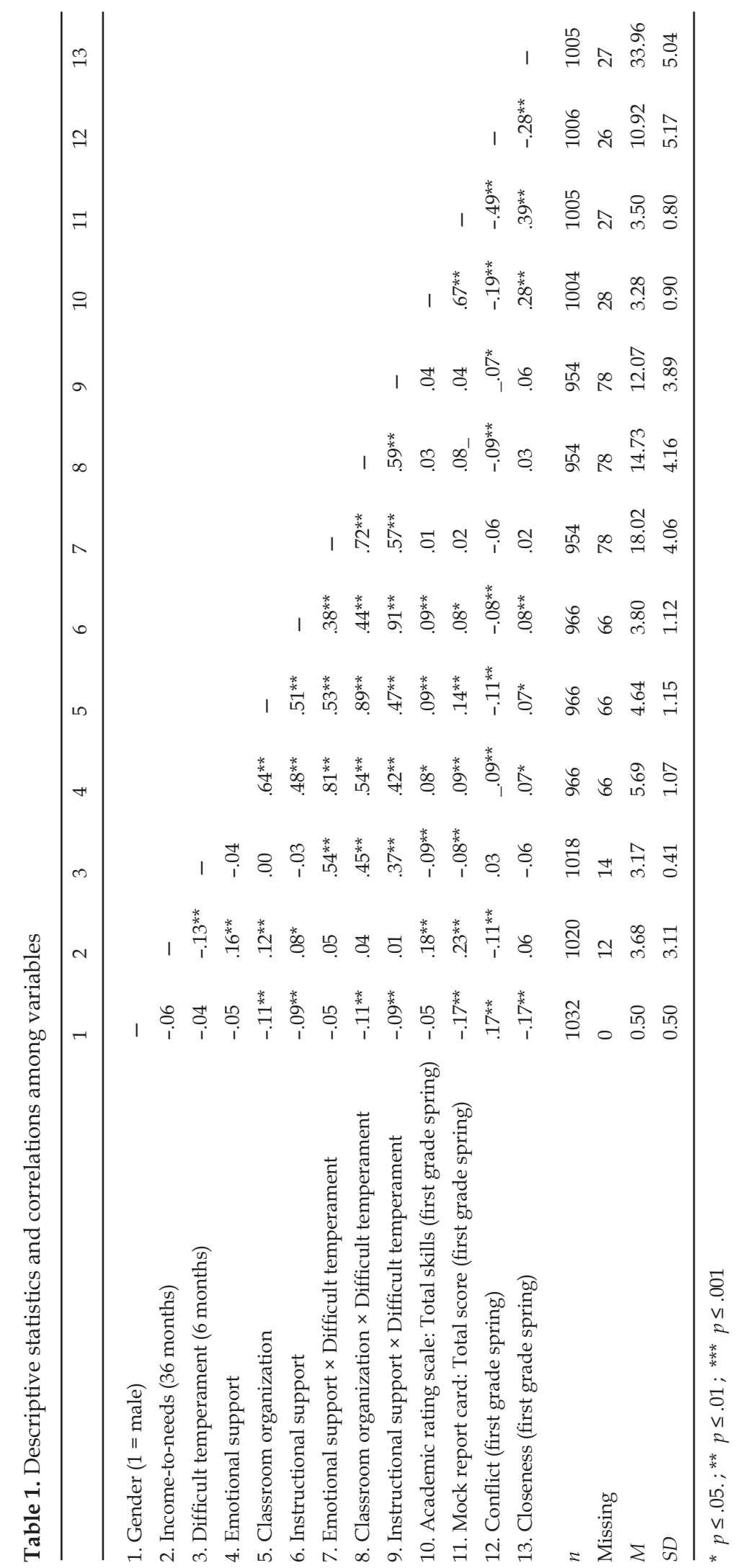




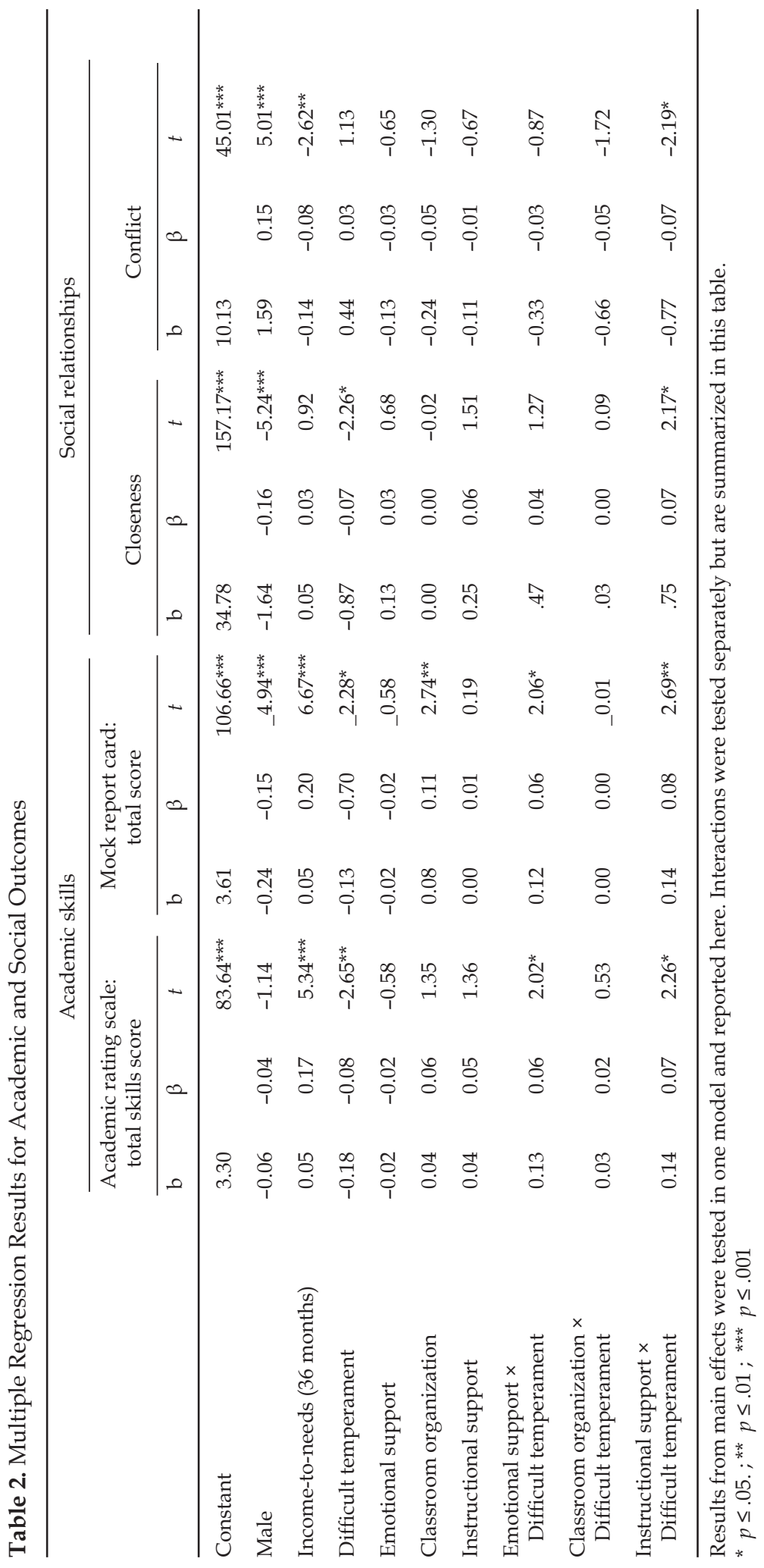




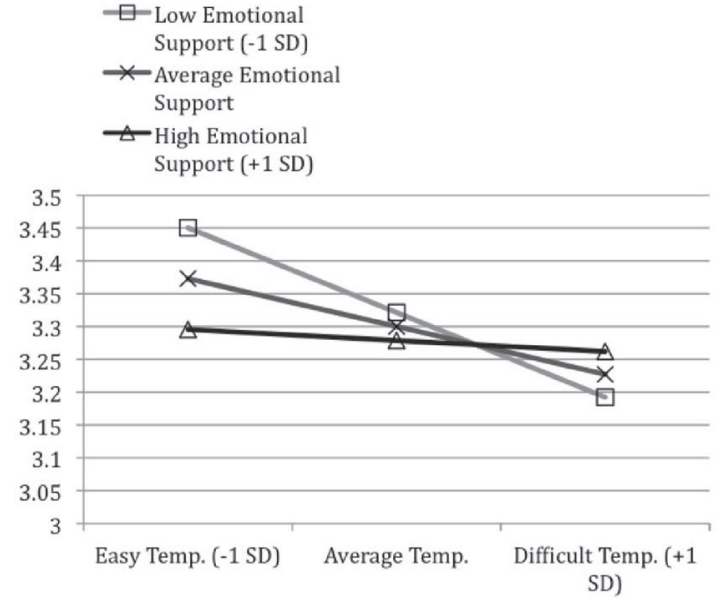

Figure 1. Emotional support $\times$ temperament interaction predicting academic rating scale scores.

The emotional support $\times$ difficult temperament interaction was a significant predictor for both academic outcomes: the Academic Rating Scale $(b=.13, p<, 05)$ and Mock Report Card $(b$ $=.12, p<.05)$. Figure 1 depicts the interaction for the Academic Rating Scale, which was very similar to results from the model predicting Mock Report Card scores. Results suggest that in classrooms with higher emotional support, there was little relation between a child's temperament and their academic skills, but in classrooms with low emotional support, the effects of temperament varied. Specifically, children with less difficult temperaments scored higher academically when they were placed in classrooms with lower levels of emotional support, whereas children with more difficult temperaments scored higher academically when they were placed in classrooms with higher levels emotional support. The instructional support $\times$ difficult temperament interaction was a significant predictor of academic and social outcomes. Specifically, instructional support $\times$ difficult temperament predicted scores for the Academic Rating Scale $(b=.14, t=2.26, p$ $<.05)$, the Mock Report Card $(b=.14, t=2.69, p<$ $.01)$, teacher-child closeness $(b=.75, t=2.17, p<$ $.05)$, and teacher-child conflict $(b=-.77, t=-2.19$, $p<.05)$. Figure 2 depicts the results from teacherchild closeness, and the other outcomes showed a similar pattern. In these instances, children in classrooms with higher instructional support were

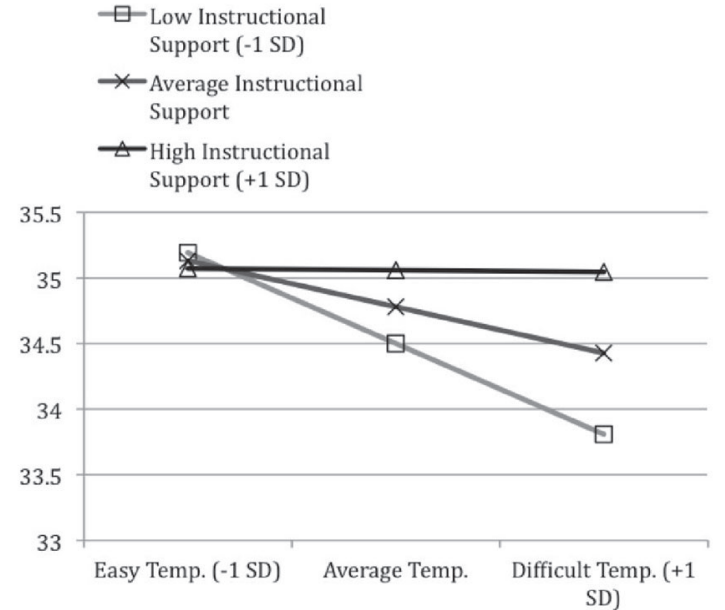

Figure 2. Instructional support $\times$ temperament interaction predicting closeness with teacher.

rated similarly, regardless of their level of difficult temperament. However, in classrooms with lower instructional support, children with a more difficult temperament had poorer scores for academic and social outcomes than their peers with a less difficult temperament.

\section{Discussion}

The main finding from the present study is that high-quality classroom interactions may ameliorate risks associated with children's difficult temperaments. Consistent with prior findings suggesting high classroom quality can buffer against some of the academic and social risks associated with certain child characteristics (Hamre \& Pianta, 2005; Rimm-Kaufman et al., 2002; Rudasill, Gallagher, et al., 2010), we found support for the notion that emotional and instructional aspects of highquality classroom environments can buffer against some of the negative effects of having a difficult temperament.

\section{Academic Outcomes}

Why might children with difficult temperaments thrive academically in high-quality environments? Our data suggest the answer varies based on the domain of classroom interactions and the outcomes of interest (cf., Curby, Rimm- 
Kaufman, \& Ponitz, 2009). For academic outcomes, emotional support interacted with temperament to predict Academic Rating Scale and Mock Report Card scores. This suggests that emotional support may be particularly salient to children during first grade. Although formal schooling begins for children in kindergarten, the transition into first grade can be particularly daunting for many students (Rimm-Kaufman \& Pianta, 2000). In first grade, work demands increase as well as expectations for children to be able to do self-directed work. The challenges associated with the transition to first grade may be especially challenging for children with difficult temperaments. A hallmark of a more difficult temperament is difficulty adjusting to new places and situations. Thus, a teacher who is sensitive and fosters a positive classroom environment may make it easier for a child with a difficult temperament to engage in the available learning tasks. In this way, an emotionally supportive teacher may provide a particularly better fit for children with difficult temperaments ( $\mathrm{Ru}-$ dasill, Gallagher, et al., 2010). This is consistent with work by Hamre and Pianta (2005) indicating higher-quality classroom contexts ameliorate risk for academic difficulties in young children.

In more emotionally supportive classrooms, the effect of temperament is practically nonexistent. In other words, children with easy or difficult temperaments have similar outcomes when they are in classrooms with higher levels of emotional support. In this way, higher emotional support acts as a buffer against the risks of lower academic outcomes associated with difficult temperament, allowing children, regardless of temperament, to flourish academically. This supports the notion that higher levels of emotional support set the stage for higher-quality instruction to take place (cf., Curby, Grimm, \& Pianta, 2010), at least for children with more difficult temperaments.

In classrooms with lower emotional support, however, a different picture emerges. It appears, upon inspection of Figure 1, children with an easier temperament actually do worse academically in classrooms with higher levels of emotional support than in classrooms with lower levels of emotional support. We suspect this may have something to do with the amount of overcontrol in the classroom (a dimension of emotional support; a classroom with higher emotional support has a lower level of over- control). Overcontrol measures the degree to which the teacher is highly directive of children's activities. Children with easy versus difficult temperaments may respond differently to these directives from the teacher. Children with easy temperaments are likely to adapt more quickly to variations in classroom and teacher characteristics than a child with a difficult temperament. It may be that an easier temperament (e.g., higher adaptability) allows a child to use the teacher directives as the teacher intends them (i.e., as a learning opportunity) without being stifled. However, given the unexpected nature of this finding, further research is warranted to investigate this claim.

Instructional support was also found to moderate the relationship between difficult temperament and academic outcomes. Children in classrooms with higher levels of instructional support scored about the same, regardless of temperament, whereas children with difficult temperaments in classrooms with lower levels of instructional support scored worse. In this way, higher-quality instructional support levels the playing field for students with varying temperaments. Higher classroom quality has been shown to promote higher achievement through children's engagement (Ponitz, Rimm-Kaufman, Grimm, \& Curby, 2009). Therefore, the present study suggests that teachers of children with more difficult temperaments may be providing more ways for the children to engage in the classroom environment, thus promoting higher achievement.

\section{Social Outcomes}

With regard to children's social outcomes (i.e., teacher-child relationships), instructional support was the strongest predictor of closeness and conflict for children with varying levels of difficult temperament. Once again, we see the pattern that in classrooms with higher levels of instructional support, temperament matters little (i.e., children with easy and difficult temperaments score similarly). However, in classrooms with lower levels of instructional support, children with more difficult temperaments had less closeness and more conflict with teachers than their peers with easier temperaments. This adds support to the notion that classroom quality can ameliorate the risks associated with difficult temperament. 
Instructional support may be the salient moderator of this relationship because children with more difficult temperaments may be less adaptive and active and, therefore, need more instructional conversation or feedback to develop and maintain positive relationships with their teachers. Because closeness and conflict are related to academic, behavioral, and social outcomes (e.g., Birch \& Ladd, 1997), temperament is likely also having indirect effects on these later outcomes, too.

Notably, organizational support did not seem to differ in its effects for children of varying levels of difficult temperament for these outcomes. There was a main effect when looking at grades based on the Mock Report Card, whereby children in more organized classrooms were reported as having higher grades. The present study, therefore, suggests that efforts to improve classroom organization may be beneficial for academics regardless of children's temperament.

\section{Limitations and Future Directions}

Although we had different reporters (mothers, observers, and teachers) for the different constructs of interest (temperament, classroom interactions, and school outcomes, respectively), we do not know the degree to which our results are contingent upon using this particular constellation of reporters. For example, it could be that less supportive teachers rate students with difficult temperaments more harshly. Future work could examine these relations using other nonteacher-report measures.

As with any correlational study, we can only say the "effects" seen in the present study are associations between variables as opposed to causal links between the variables. To increase the causal inference about the effects of classroom interactions moderating associations between children's temperament and outcomes, children with varying temperaments could be randomly assigned to classrooms. It would also be helpful to have a nested dataset whereby multiple students of varying temperaments have the same teachers. In this way, at a minimum, future work could replicate findings from the current study to examine whether the relationships hold not only using a different sample but also using different analyses that would examine these relationships within a classroom (and not just between classrooms as in the present analyses).

Although temperament is manifest in coherent behavioral and socioemotional profiles that are evident in the first months of life (Rothbart, 1981), these profiles are only relatively stable over time. As such, a great deal of the literature has specifically focused on what secondary factors both internal (e.g., attention, psychophysiology) and external (e.g., parenting, social environment) to the child can help account for the relative instability of temperament over time (Fox, Henderson, Rubin, Calkins, \& Schmidt, 2001; Kagan, Snidman, Kahn, \& Towsley, 2007). The current study expands on this line of research by incorporating a centrally important force in the development of children, the classroom environment (Rimm-Kaufman \& Kagan, 2005; Rudasill, Gallagher, et al., 2010). Within this larger question, our focus is explicitly on how infant temperament is linked to differential susceptibility to moderating forces-even in the face of additional factors known to be at play in the intervening years between infancy and first grade. Nonetheless, the unreliability of the temperament instrument used in the present study is a limitation. Future research could examine the extent to which the present study's findings are replicated when using different types of temperament measures (e.g., direct assessment) at different time points.

We also wonder about the degree to which these findings generalize over grades. As temperament continues to be modified in some ways and cemented in others (Fox et al., 2001), it may be that children's responses to the classroom environment change. In other words, in line with differential susceptibility theory (Belsky \& Pluess, 2009), might children with difficult temperament be more susceptible to the negative and positive effects of classroom at a younger age? Future work with kindergarten or prekindergarten children could address this question.

A related area for future research would be to examine how children's gender and race/ethnicity might affect the results of this study, particularly given the teacher-reported outcomes used (Ehrenberg, Goldhaber, \& Brewer, 1995). It is plausible that some of the findings in the present study are better explained by these other factors that have been linked to teacher perceptions of students' abilities. It is also plausible that these other 
factors might mediate or moderate some of the associations found in the present study. Mantzicopoulos and Neuharth-Pritchett (2003) found negative associations between children's perceptions of teacher support in preschool and their concurrent and later academic and social skills. The fact that teacher support in preschool predicted academic and social outcomes suggests that teacher-child relationships may mediate associations between child characteristics and important outcomes (and this is supported elsewhere, such as in Rudasill, Reio, Stipanovic, \& Taylor, 2010). In addition, consistent with findings based on teacher reports of teacher-child relationship quality, Mantzicopoulos and Neuharth-Pritchett found that boys and African American students reported lower perceptions of teacher support. This finding suggests that links between child gender and race and teacher-child relationship quality extend beyond the influence of teacher perceptions.

\section{Implications}

The present study offers insight into the experiences of children with more difficult temperaments in classrooms and into possible avenues for teachers to modify their practices to better meet the needs of their students. To the extent that temperament changes over time, one force in that change to be considered is the time spent in an out-of-home environment, particularly school. As formal schooling begins, children begin to conceptualize their attitudes toward school. As children's academic trajectories are being established (Alexander, Entwisle, Blyth, \& McAdoo, 1988), the early experiences they have with teachers may play an important formative role. Thus, the present study suggests that as children with different temperaments experience their interactions with teachers differently, they may not only have different outcomes for that year but may be developing an academic identity that could have longer-term positive or negative consequences (Rimm-Kaufman \& Pianta, 2000).

Findings from this study are congruent with previous research indicating children with various risk factors disproportionately benefit from highquality classroom environments (Hamre \& Pianta, 2005). From this vantage point, children with more difficult temperaments are more at risk for negative outcomes than children with easier temper- aments. What can be done to ameliorate this risk? The present study suggests that higher-quality classroom environments may buffer children with more difficult temperaments from negative outcomes. Thus, interventions that promote higherquality emotional, organizational, and instructional environments may enable teachers to provide a better fit for children with difficult temperaments. Interventions have been implemented that support the idea that the quality of teacher-student interactions is, at least in part, a malleable characteristic of teachers (e.g., Pianta, Mashburn, Downer, Hamre, \& Justice, 2008). However, as of yet, none of these types of interventions are operating at scale. Thus, the impetus falls to schools themselves to incorporate these ideas into their professional development programs. Should schools find ways to increase the quality of the classroom interactions, at-risk children-including those with difficult temperaments - will reap the rewards.

\section{References}

Adams, M. J. (1990). Beginning to read: Thinking and learning about print. Cambridge, MA: MIT Press.

Aiken, L. S., \& West, S. G. (1991). Multiple regression: Testing and interpreting interactions. Newbury Park, CA: Sage.

Alexander, K. L., Entwisle, D. R., Blyth, D. A., \& McAdoo, H. P. (1988). Achievement in the first two years of school: Patterns and processes. Monographs of the Society for Research in Child Development, 53, 1-157.

Alexander, K. L., Entwisle, D. R., \& Dauber, S. L. (1993). First-grade classroom behavior: Its short- and longterm consequences for school performance. Child Development, 64, 801-814.

Baker, J. A. (2006). Contributions of teacher-child relationships to positive school adjustment during elementary school. Journal of School Psychology, 44, 211-229.

Belsky, J., \& Pluess, M. (2009). The nature (and nurture?) of plasticity in early human development. Perspectives on Psychological Science, 4, 345-351.

Birch, S. H., \& Ladd, G. W. (1997). The teacher-child relationship and children's early school adjustment. Journal of School Psychology, 35(1), 61-79.

Bradley, R. H., \& Corwyn, R. F. (2009). Infant temperament, parenting, and externalizing behavior in first grade: A test of the differential susceptibility hypothesis. The Journal of Child Psychology and Psychiatry, 49, 124-131. 
Bronfenbrenner, U., \& Morris, P. A. (2006). The bioecological model of human development. In W. Damon (series Ed.) \& R. M. Lerner (vol. Ed.), Handbook of Child Psychology: Vol. 1 Theoretical models of human development (5th ed.), (pp. 994-1028). New York: Wiley.

Carey, W. B. (2005). Understanding your child's temperament. New York: Macmillan.

Carey, W. B., \& McDevitt, S. C. (1978). Revision of the infant temperament questionnaire. Pediatrics, 61, 735-739.

Caspi, A., Bem, D. J., \& Elder, G. H. (2006). Continuities and consequences of interactional styles across the life course. Journal of Personality, 57, 375-406.

Conger, R. D., Conger, K. J., \& Elder, G. H. (1997). Family economic hardship and adolescent academic performance: Mediating and moderating processes. In G. J. Duncan \& J. Brooks-Gunn (Eds.), Consequences of growing up poor (pp. 288-310). New York: Russell Sage Foundation.

Curby, T. W., Grimm, K. J., \& Pianta, R. C. (2010). Stability and change in early childhood classroom interactions during the first two hours of a day. Early Childhood Research Quarterly. 25, 373-384. doi:10.1016/j. ecresq.2010.02.004

Curby, T. W., LoCasale-Crouch, J., Konold, T. R., Pianta, R., Howes, C., Burchinal, M., Barbarin, O. (2009). The relations of observed pre-k classrooms quality profiles to children's academic achievement and social competence. Early Education and Development, 20, 346-372.

Curby, T. W., Rimm-Kaufman, S. E., \& Ponitz, C. C. (2009). Teacher-child interactions and children's achievement trajectories across kindergarten and first grade. Journal of Educational Psychology, 101(4), 912-925.

Duncan, G. J., Dowsett, C. J., Claessens, A., Magnuson, K., Huston, A. C., Klebanov, P., Brooks-Gunn, J. (2007). School readiness and later achievement. Developmental Psychology, 43, 1428-1446.

Eccles, J. S., Midgley, C., Wigfield, A., Buchanan, C. M., Reuman, D., Flanagan, C., \& MacIver, D. (1993). Development during adolescence. American Psychologist, 48, 90-101.

Ehrenberg, R. G., Goldhaber, D. D., \& Brewer, D. J. (1995). Do teachers' race, gender, and ethnicity matter? Evidence from the National Educational Longitudinal Study of 1988. Industrial and Labor Relations Review, 48, 547-561.

Ewing, A. R., \& Taylor, A. R. (2009). The role of child gender and ethnicity in teacher-child relationship quality and children's behavioral adjustment in preschool. Early Childhood Research Quarterly, 24, 92-105.

Fox, N. A., Henderson, H. A., Rubin, K. H., Calkins, S. D., \& Schmidt, L. A. (2001). Continuity and discon- tinuity of behavioral inhibition and exuberance: Psychophysiological and behavioral influences across the first four years of life. Child Development, 72, 1-21.

Garcia Coll, C., Kagan, J., \& Reznick, J. S. (1984). Behavioral inhibition in young children. Child Development, 55(3), 1005-1019.

Ghera, M. M., Hane, A. A., Malesa, E. E., \& Fox, N. A. (2006). The role of infant soothability in the relation between infant negativity and maternal sensitivity. Infant Behavior \& Development, 29, 289-293.

Hamre, B. K., \& Pianta, R. C. (2005). Can instructional and emotional support in the first grade classroom make a difference for children at risk of school failure? Child Development, 76, 949-967.

Hamre, B. K., \& Pianta, R. C. (2007). Learning opportunities in preschool and early elementary classrooms. In R. C. Pianta, M. J. Cox, \& K. Snow (Eds.), School readiness and the transition to kindergarten (pp. 49-84). Baltimore: Brookes Publishing Co.

Hamre, B. K., Pianta, R. C., Mashburn, A., \& Downer, J. (2007). Building and validating a theoretical model of classroom effects in over 4,000 early childhood and elementary classrooms. Retrieved from the Foundation for Child Development: http://www.fcd-us. org/resources/building-science-classrooms-application-class-framework-over-4000-us-early-childhoodand-e?destination $=$ resources $\% 2$ Fsearch $\% 3$ Fpage \%3D10

Hane, A. A., Cheah, C. S. L., Rubin, K. H., \& Fox, N. A. (2008). The role of maternal behavior in the relation between shyness and social withdrawal in early childhood and social withdrawal in middle childhood. Social Development, 17, 795-811.

Hart, B., \& Risley, T. (1995). Meaningful differences in everyday experience of young American children. Baltimore: Paul Brookes Publishing Co.

Hart, D., Atkins, R., \& Fegley, S. (2003). Personality and development in childhood: A person-centered approach. Monographs of the Society for Research in Child Development, 68, vii-109.

Kagan, J., Snidman, N., Kahn, V., \& Towsley, S. (2007). The preservation of two infant temperaments into adolescence. Monographs of the Society for Research in Child Development, 72, 1-75.

Keogh, B. (2003). Temperament in the classroom: Understanding individual differences. Baltimore: Brookes Publishing Co.

Lerner, J. (1983). The influence of child temperamental characteristics on parent behaviors. In T. Luster and L. Okagaki (Eds.), Parenting: An ecological perspective (pp. 101-120). Hillsdale, NJ: Erlbaum.

Liew, J., Chen, Q., \& Hughes, J. N. (2010). Child effortful control, teacher-student relationships, and achievement in academically at-risk children: Additive and 
interactive effects. Early Childhood Research Quarterly, 25, 51-64.

Mantzicopoulos, P., \& Neuharth-Pritchett, S. (2003). Development and validation of a measure to assess Head Start children's appraisals of teacher support. Journal of School Psychology, 41, 431-451.

Martin, R. P., Drew, K. D., Gaddis, L. R., \& Moseley, M. (1988). Prediction of elementary school achievement from preschool temperament: Three studies. School Psychology Review, 17, 125-137.

Martin, R. P., \& Holbrook, J. (1985). Relationship of temperament characteristics to the academic achievement of first-grade children. Journal of Psychoeducational Assessment, 3, 131-140.

Mashburn, A. J., Pianta, R., Hamre, B. K., Downer, J. T., Barbarin, O., Bryant, D., . . Howes, C. (2008). Measures of classroom quality in pre-kindergarten and children's development of academic, language and social skills. Child Development, 79, 732-749.

McKnight, P. E., McKnight, K. M., Sidani, S., \& Figueredo, A. J. (2007). Missing data: A gentle introduction. New York: Guilford Press.

Molfese, V. J., Rudasill, K. M., Beswick, J. L., Jacobi-Vessels, J. L., Ferguson, M. C., \& White, J. M. (2010). Infant temperament, maternal personality, and parenting stress as contributors to infant developmental outcomes. Merrill-Palmer Quarterly, 56, 49-79.

National Center for Education Statistics.(no date). Academic rating scale. Washington, DC: National Center for Education Statistics.

NICHD ECCRN. (2003). Social functioning in first grade: Prediction from home, child care and concurrent school experience. Child Development, 74, 1639-1662.

Pianta, R. C. (2001). Student-teacher relationship scale. Lutz, FL: Psychological Assessment Resources, Inc.

Pianta, R. C., La Paro, K. M., \& Hamre, B. K. (2008). Classroom Assessment Scoring System (CLASS) pre-K version. Baltimore: Brookes Publishing Co.

Pianta, R. C., Mashburn, A. J., Downer, J. T., Hamre, B. K., \& Justice, L. (2008). Effects of web-mediated professional development resources on teacher-child interactions in pre-kindergarten classrooms. Early Childhood Research Quarterly, 23, 431-451.

Pierce, K. M., Hamm, J. V., \& Vandell, D. L. (1999). Experiences in after-school programs and children's adjustment in first-grade classrooms. Child Development, 70, 756-767.

Ponitz, C. C., Rimm-Kaufman, S. E., Grimm, K. J., \& Curby, T. W. (2009). Kindergarten classroom quality, behavioral engagement, and reading achievement. School Psychology Review, 38(1), 102-120.
Prior, M. (1992). Childhood temperament. Journal of Child Psychology \& Psychiatry, 33, 249-279.

Rimm-Kaufman, S., \& Pianta, R. (2000). An ecological perspective on the transition to kindergarten: A theoretical framework to guide empirical research. Journal of Applied Developmental Psychology, 21(5), 491-511.

Rimm-Kaufman, S. E., Curby, T. W., Grimm, K. J., Nathanson, L., \& Brock, L. L. (2009). The contribution of children's self-regulation and classroom quality to children's adaptive behaviors in the kindergarten classroom. Developmental Psychology, 45, 958-972.

Rimm-Kaufman, S. E., Early, D. M., Cox, M. J., Saluja, G., Pianta, R. C., Bradley, R. H., \& Payne, C. (2002). Early behavioral attributes and teachers' sensitivity as predictors of competent behavior in the kindergarten classroom. Applied Developmental Psychology, 23, 451-470.

Rimm-Kaufman, S. E., \& Kagan, J. (2005). Infant predictors of kindergarten behavior: The contribution of inhibited and uninhibited temperament types. Behavioral Disorders, 30, 331-347.

Rothbart, M. K. (1981). Measurement of temperament in infancy. Child Development, 52, 569-578.

Rothbart, M., Ahadi, S., \& Evans, D. (2000). Temperament and personality: Origins and outcomes. Journal of Personality and Social Psychology, 78, 122-135.

Rudasill, K. M., Gallagher, K. C., \& White, J. M. (2010). Temperamental attention and activity, classroom emotional support, and academic achievement in third grade. Journal of School Psychology, 48, 113-134.

Rudasill, K. M., Reio, T., \& Stipanovic, N., \& Taylor, J. E. (2010). A longitudinal study of student-teacher relationship quality, difficult temperament, and risky behavior from childhood to early adolescence. Journal of School Psychology, 48, 389-412.

Rudasill, K. M., \& Rimm-Kaufman, S. E. (2009). Teacherchild relationship quality: The roles of child temperament and teacher-child interactions. Early Childhood Research Quarterly, 24, 107-120.

Rudasill, K. M., Rimm-Kaufman, S. E., Justice, L. M., \& Pence, K. (2006). Temperament and language skills as predictors of teacher-child relationship quality in preschool. Early Education and Development, 17, 271-291.

Schafer, J. L. (1997). Analysis of incomplete multivariate data. London: Chapman \& Hall.

Stright, A. D., Gallagher, K. C., \& Kelly, K. (2008). Infant temperament moderates relations between maternal parenting in early childhood and children's adjustment in first grade. Child Development, 79, 186-200.

Thomas, A., \& Chess, S. (1977). Temperament and development. New York: Brunner/Mazel. 